\title{
'Carolina Cayenne' as a Source of Resistance to Meloidogyne incognita Races 1, 2, 3, and 4
}

\author{
E. Zamora and P.W. Bosland \\ Department of Agronomy and Horticulture, New Mexico State University, Las \\ Cruces, NM 88003
}

S. Thomas

Department of Entomology, Plant Pathology and Weed Science, New Mexico
State University, Las Cruces, NM 88003

Additional index words. Capsicum annuum, chile, red pepper, plant breeding

Abstract. The resistance of 'Carolina Cayenne' (Capsicum annuum L.) to root-knot nematode Meloidogyne incognita (Kofoid \& White) Chitwood races 1, 2, 3, and 4 was measured. Egg counts from roots were used to determine the plant's resistance to $M$. incognita. Few eggs were observed on 'Carolina Cayenne' roots, whereas all races of $M$. incognita produced numerous eggs on the susceptible 'NuMex $R$ Naky' roots. The results indicated 'Carolina Cayenne' is a source of resistance to all known races of $M$. incognita.

Root knot, a major root disease of chile, is caused by the nematode Meloidogyne incognita (Kofoid \& White) Chitwood. Historically, nematicides have been the first choice in reducing damage by nematodes; however, due to the removal of several nematicides from commerce, their availability will be limited in the future. Also, the use of chemicals may raise environmental concerns. Therefore, the need for resistant chile cultivars will be important to control root-knot nematodes.

Four races have been identified within $M$. incognita. More than one race can colonize a specific crop. For example, 'Deltapine 16' cotton (Gossypium hirsutum L.) is susceptible to races 3 and 4. 'California Wonder' bell pepper (Capsicum annuum L.), 'Charleston Gray' watermelon [Citrullus lanatus (Thunb.) Matsum. \& Nakai], and 'Rutgers' tomato (Lycopersicon esculentum Mill.) are susceptible to all races of $M$. incognita (Kinloch, 1990).

Number of galls or egg masses is often reported as good indices for determining resistance (Dropkin, 1989; Taylor and Sasser, 1978). To evaluate the effect of several inoculum levels of $M$. javanica on top and root growth of 'California Wonder' pepper, Madamba et al. (1965) determined eggs per gram of root to determine susceptibility. They found statistically significant differences in top weight, root weight, and root volume between inoculated plants and the noninoculated control. Counting eggs was better than measuring gall formation for evaluating resistance to root-

Received for publication 17 May 1993. Accepted for publication 10 June 1994. A contribution of the New Mexico Agricultural Experiment Station, New Mexico State Univ., Las Cruces. The cost of publishing this paper was defrayed in part by the payment of page charges. Under postal regulations, this paper therefore must be hereby marked advertisement solely to indicate this fact. knot nematodes in C. annuum (Madamba et al., 1965). We did not determine number of egg masses; although it is a better indicator of resistance than root galls, egg mass counts can be inconsistent (Hussey and Barker, 1973). Also, results from resistance breeding efforts in cotton revealed that egg counts per egg mass vary with the level of resistance expressed by the cultivar (Shepherd, 1979). Direct egg counts, as used in our study, are the most accurate method for evaluating host plant resistance to root-knot nematode reproduction (Kirkpatrick and Sasser, 1983).

In previous experiments, 'Carolina Cayenne' had a high level of resistance to $M$. incognita race 3 (Aguilar-Reyes, 1989; Fery et al., 1986). The objective of this study was to test 'Carolina Cayenne' for resistance to the other $M$. incognita races, i.e., 1, 2, and 4.

\section{Materials and Methods}

When 'Carolina Cayenne' and 'NuMex R Naky' seedlings had four true leaves, they were inoculated with $M$. incognita races 1,2 , 3, and 4. 'Carolina Cayenne' is resistant to race 3, and 'NuMex $\mathrm{R}$ Naky' is susceptible. The seedlings were grown in a commercial peat-lite mixture in plant cells $(3 \times 4 \times 5.8 \mathrm{~cm})$. A randomized complete-block design with four replications was used. Each replicate contained 12 seedlings per genotype per race. A greenhouse bench heating pad maintained the soil temperature at $27 \mathrm{C}$.
The $M$. incognita races 1 and 2 used in this experiment were identified and provided by Kenneth C. Barker, Dept. of Plant Pathology, North Carolina State Univ. The $M$. incognita races 3 and 4 were provided by the Dept. of Entomology, Plant Pathology and Weed Science, New Mexico State Univ. Race 1 and race 3 eggs were collected from tomato. Race 2 eggs were collected from asparagus (Asparagus officinalis L.). Race 4 eggs were collected from tobacco (Nicotiana tabacum L.). The nematode eggs were removed from plant roots using standard $\mathrm{NaOCl}$ extraction procedures (Barker, 1985). The cultivars were inoculated on the same day that the eggs were extracted.

Nematode eggs were quantified using a hemacytometer. Each 36-day-old seedling was inoculated with $1 \mathrm{ml}$ of a suspension of 1500 eggs $/ \mathrm{ml}$. To avoid leaching of nematode eggs during the first 2 weeks after inoculation, each seedling was carefully irrigated with 5 to $6 \mathrm{ml}$ of water per seedling, as needed. To evaluate characteristics of resistance by means of egg counts, which is a laborious effort, three randomly chosen 71- to 75-day-old plants per cultivar and per treatment per replication were chosen. The eggs were recovered using the $\mathrm{NaOCl}$ procedure (Barker, 1985). Egg counts from each plant were determined by counting $1 \mathrm{ml}$ from a $10-\mathrm{ml}$ suspension of all eggs recovered from the root system. The dry root weight for each plant was determined by placing fresh root systems into an oven at $110 \mathrm{C}$ for $48 \mathrm{~h}$; they were cooled and then weighed.

\section{Results and Discussion}

Statistically significant differences in egg production per gram of dry root were observed between the resistant and susceptible cultivars and among the four nematode races. The interaction effect between nematode races and cultivars was also significant (Table 1). 'Carolina Cayenne' is a good source of resistance to all known races of $M$. incognita (Table 2). The roots of 'Carolina Cayenne' were free of galls, although some eggs were recovered (Table 2). All races of $M$. incognita produced galls and eggs on the susceptible 'NuMex R Naky'. Race 3 was the most aggressive with respect to egg production of the four races. As this is the only race found on chile in New Mexico, these results may reflect adaptation to the crop. The significant interaction between races and cultivars in this experiment is also largely explained by the aggressiveness of race 3 . Even though $M$. incognita race 3 produced eggs on 'Carolina Cayenne', this cultivar can be considered resistant due to the $99.9 \%$ reduction in egg counts when compared to the susceptible 'NuMex R Naky' cultivar. Consequently,

Table 1. Analysis of variance of root-knot nematode (Meloidogyne incognita) egg production per gram of dry root tissue in the chile cultivars Carolina Cayenne and NuMex R Naky.

\begin{tabular}{lrrrrr}
\hline \hline Source & df & \multicolumn{1}{c}{ SS } & \multicolumn{1}{c}{ MS } & \multicolumn{1}{c}{ F } & $P>\mathrm{F}$ \\
\hline Replicates & 3 & 142623.61 & 47541.20 & 0.33 & 0.8019 \\
Cultivars & 1 & 12891892.69 & 12891892.69 & 90.16 & 0.0001 \\
Nematode races & 3 & 4133466.07 & 1377822.02 & 9.64 & 0.0001 \\
Race $\times$ cultivar & 3 & 3963990.73 & 1321330.24 & 9.24 & 0.0001 \\
Error & 21 & 9151063.72 & 142985.37 & & \\
\hline
\end{tabular}


Table 2. Comparison of number of root-knot nematode (Meloidogyne incognita) eggs recovered and presence or absence of galling on 'Carolina Cayenne' and 'NuMex R Naky' chile pepper root systems.

\begin{tabular}{lccc}
\hline Cultivar & Nematode race & Gall formation & Eggs/gram dry root tissue \\
\hline Carolina Cayenne & 1 & No & $15 \mathrm{a}$ \\
& 2 & No & $15 \mathrm{a}$ \\
& 3 & No & $124 \mathrm{~b}$ \\
NuMex R Naky & 4 & No & $37 \mathrm{a}$ \\
& 1 & Yes & $37,100 \mathrm{a}$ \\
& 2 & Yes & $63,600 \mathrm{a}$ \\
& 3 & Yes & $143,000 \mathrm{~b}$ \\
\hline
\end{tabular}

${ }^{2}$ Mean separation within cultivar by Duncan's multiple range test $(P \leq 0.01)$.

introgressing resistance gene(s) for all four races of $M$. incognita from 'Carolina Cayenne' into other cultivars likely is possible.

\section{Literature Cited}

Aguilar-Reyes, E.L. 1989. A technique for screening Capsicum seedlings for resistance to the southern root-knot nematode (Meloidogyne incognita) and evaluation of genetic resistance of supposedly nematode resistant Capsicum accessions. MS Thesis, New Mexico State Univ., Las Cruces.

Barker, K.R. 1985. Nematode extraction and bioassays, p. 19-35. In: K. Barker, C.C. Carter, and J.N. Sasser (eds.). An advanced treatise on Meloidogyne. Volume II: Methodology. North Carolina State Univ. Graphics, Raleigh.

Dropkin, V.H. 1989. Introduction to plant nematology. 2nd ed. Wiley Interscience, New York.
Fery, R.L., P.D. Dukes, and W.L. Ogle. 1986. 'Carolina Cayenne’ pepper. HortScience 21:330.

Hussey, R.S. and K.R. Barker. 1973. A comparison of methods of collecting inocula of Meloidogyne spp., including a new technique. Plant Dis. Rptr. 57:1025-1028.

Kinloch, R.A. 1990. Screening for resistance to root-knot nematodes, p. 16-28. In: J.L. Starr (ed.). Methods for evaluating plant species for resistance to plant-parasitic nematodes. Soc. Nematologists, Hyattsville, Md.

Kirkpatrick, T.L. and J.N. Sasser. 1983. Parasitic variability of Meloidogyne incognita populations on susceptible and resistant cotton. J. Nematol. 15(2):302-307.

Madamba, C.P., J.N. Sasser, and L.A. Nelson. 1965 Some characteristics of the effects of Meloidogyne spp. on unstable host crops. North Carolina Agr. Expt. Sta., Raleigh, Tech. Bul. 169:1-34.

Taylor, A.L. and J.N. Sasser. 1978. Biology, identification and control of root-knot nematodes Meloidogyne species. North Carolina State Univ. Graphics, Raleigh. 